Published in Castree N., Hulme, M. \& Proctor, J. 2018 Companion to Environmental Studies. Routledge

\title{
Public engagement with environmental science
}

\section{By Helen Pallett}

Approaches to public engagement with environmental science have been as varied and contested as the environmental sciences themselves. While often presented as a twentieth century invention, public engagement dates back to the inception of the environmental sciences as formal disciplines, and has evolved alongside them. Public engagement projects and programmes have not only drawn from advances in the environmental sciences, but have also contributed significantly to them. Formal public engagement with science activities have often been based on misconceptions about the public, presenting them as irrational and lacking in understanding. However, publics have resisted and defied this narrow categorisation through the variety of ways in which they have engaged with the environmental sciences.

\section{Public engagement at the establishment of environmental sciences}

The early foundations of the study of the environmental sciences were laid by the gentleman explorers of the eighteenth and nineteenth centuries. Access to this social world was as much to do with one's background and resources as it was about having formal scientific training. These explorers, led by figures such as Alexander von Humbolt, began to systematically chart and record the flora and fauna they encountered in far-flung corners of the globe, creating the outlines of classificatory systems still used today by biologists and ecologists. They also began to map and richly describe these regions as a precursor to the development of geography as a discipline.

Early conservationists, too, were not professional scientists, but rather were concerned and often wealthy citizens responding to the environmental destruction they were witnessing as western states modernised and industrialised. These conservationists set about systematically monitoring important populations and habitats to provide evidence of their decline and to test their efforts at conservation. The evidence they amassed was also bolstered by the work of often less wealthy amateurs such as bird watchers, anglers and plant enthusiasts who had been doing monitoring of their own. They also created associations and trusts, such as the Sierra Club and the National Trust, to provide long term funding for these efforts, creating resources and laying the foundations for field sciences like ecology. While the development of colonial field sciences beyond the West was often a story of domination, sometimes these disciplines also advanced by learning from indigenous peoples.

The development of the meteorological sciences was also enabled in no small part by the labours of lay observers, in creating large data sets to work from and beginning to infer connections between different aspects of the weather. Large networks of lay observers remained central to the work of predicting and understanding weather systems well into the twentieth century, and indeed are still vital in some areas of meteorology. 
Published in Castree N., Hulme, M. \& Proctor, J. 2018 Companion to Environmental Studies. Routledge

The professionalization of the environmental sciences and their formalisation as disciplines through the eighteenth and nineteenth centuries was driven in part by concerns about the rationality and level of understanding of the lay public, which have been echoed in debates about public engagement ever since. At this time it was public outrage about emerging theories of evolution, as well as new ways of thinking about environmental change from geology, which conflicted with accepted religious teachings, which animated these discussions. Therefore, the founding of the environmental sciences, though dependent on much work by amateurs, was also predicated on the exclusion of much of the public from the practice of science in order to create a new elite of professional scientists who practiced their craft in a rigorous and systematic way. However, while the lay public were removed from the day to day practice of the environmental sciences, a particular kind of public wealthy, respectable, male - still had an important role in witnessing and therefore validating scientific claims and findings through the emergent experimental method. It was at this very point when the role of the public in the environmental sciences had been judiciously curtailed that discussions about the 'popularisation of science' namely the need to be more engaged with this lay public - began (Shapin, 1990).

\section{Communicating the environmental sciences}

The Victorian passion for the popularisation of science through travelling road shows, educational books, museums, public gardens and more has left a lasting legacy. In the post-war years of the twentieth century, in response to widespread public unease with certain developments in science such as new energy technologies or the role of scientific advances in warfare, this project was reframed in terms of the public understanding of science, rather than its popularisation. Both governments and scientific institutions saw public unease and distrust of science as a threat, and believed it was a consequence of a lack of understanding of scientific facts and principles. They believed that better communication and education of science would improve public acceptance of controversial scientific advances and policies.

Science communication was the burgeoning academic field and industry set up to respond to this crisis in public confidence, using many of the same tools as the popularisation of science movement. This was also supported by the creation of new institutions, such as the Government's Committee on the Public Understanding of Science and the British Science Association in the UK. It remains a thriving field encompassing activities as diverse as documentaries, corporate social responsibility agendas, and the increasing onus placed on academics to communicate their findings beyond the academy.

However, cracks have also emerged in this project, revealing the limits of this oneway public engagement. Around high profile environmental science controversies towards the end of the twentieth century, such as the BSE (Mad Cow disease) crisis, continuing debates about nuclear power and waste, and the introduction of genetically modified organisms (GMOs) into the food system, science communication has failed to diffuse controversy and opposition as had been hoped. One of the reasons for this is that public distrust of and unease with science was not 
Published in Castree N., Hulme, M. \& Proctor, J. 2018 Companion to Environmental Studies. Routledge

only down to a lack of scientific understanding, but rather resulted from people holding fundamentally different values and visions of the future to governing institutions (Jasanoff, 2005). Therefore, repeatedly telling people that they were wrong to be concerned about issues like BSE or GMOs - and in some cases exaggerating the level of certainty about the scientific facts - was not enough to convince people who also had concerns about social justice, regulation and other ethical dimensions. Furthermore, public groups continually demonstrated that in many cases they were not ignorant of the scientific facts, but rather were basing their positions on forms of counter expertise, sometimes showing superior knowledge about environmental impacts on their local areas, or choosing to monitor and measure different elements.

Two-way public engagement has been proposed as a response to this apparent impasse, allowing for much more active public participation around environmental issues and the environmental sciences rather than merely passive acceptance. This has emerged from a recognition of the substantive role lay publics could play in debating the ethical dimensions of environmental issues and contributing relevant situated knowledges to the discussion. More instrumentally, governing institutions have realised that two-way engagement is also more likely to obtain the public 'buyin' necessary to enable the radical societal transformations which will be required to address environmental problems such as climate change, or restructuring food systems. As a result public participation has become an institutionalised and in many cases routine part of environmental science and governance, encompassing local government planning decisions, government agencies, scientific projects and national policy-making.

\section{Citizen science and environmental activism}

The term 'citizen science', often attributed to Alan Irwin (1995), describes the involvement of lay publics in the actual practice of science, which as this chapter has shown, has been a long-running endeavour. Contemporary citizen science projects are perhaps the most high-profile and widespread instances of public engagement with environmental sciences. These projects are often orchestrated by professional scientists, but then involve large numbers of the lay public in carrying out scientific tasks such as species counts, measuring environmental quality, and even analysing parts of large data sets. The exponential increase in these kinds of projects has revolutionised certain areas of the environmental sciences by providing a large and willing labour force without which some kinds of data collection and analysis would not be possible. Furthermore, social media platforms have made it increasingly easy to recruit and communicate with this labour force. However, these projects have sometimes been criticised for being extractive and failing to properly acknowledge the valuable contributions made by their citizen scientists.

A more foundational criticism made of these projects is that they on the whole remain firmly rooted in the conventional scientific paradigm, and therefore fail to recognise the value of other 'situated knowledges' (Haraway, 1991) such as specific local knowledge about a particular area, or entirely different knowledge systems like indigenous knowledges. This mismatch limits the contributions of citizen scientists, 
Published in Castree N., Hulme, M. \& Proctor, J. 2018 Companion to Environmental Studies. Routledge

as well as potentially restricting the pool of people who can legitimately participate in these projects. Furthermore, as citizen scientists are not usually involved in the formulation of research problems and questions - merely at the data collection and initial analysis stage - citizen science projects are not responsive to these diverse public values and knowledge systems.

Another significant area of lay public engagement around the environmental sciences is around environmental activism and environmentalism. Environmentalists themselves have long played a significant role in raising money to fund scientific projects and environmental protection efforts, and in raising broader public consciousness about environmental issues from habitat degradation, to climate change and recycling. Often environmental activists have used environmental science as a direct support to their causes. For example, the UK-based climate camp protesters famously proclaimed 'we are armed only with peer-reviewed science'. However, other environmental activists have had a more ambiguous relationships with established environmental science, sometimes marshalling their own counter expertise to challenge the dominant scientific view. For example, GMO activists challenged biologists in this way, and threatened the safe conduct of biological field trials. Around the issue of fracking, activists have challenged dominant narratives of geologists around the safety of fracking by gathering ecological and other forms of evidence about the impacts of the practice.

\section{References}

Haraway, D.J., 1991. Simians, Cyborgs, and Women: The Reinvention of Nature. London: Routledge.

Irwin, A., 1995. Citizen Science: A study of people, expertise and sustainable development. London: Routledge.

Jasanoff, S., 2005. Designs on Nature: Science and Democracy in Europe and the United States. Princeton: Princeton University Press.

Shapin, S., 1990. Science and the public. Olby, R. C.; Cantor, G. N.; Christie, J. R. R.; Hodge, M. J. S. (eds.). Companion to the History of Modern Science, pp.9901007. London: Routledge.

\section{Resources}

Buchan, K 2016. Citizen science: how the net is changing the role of amateur researchers. The Guardian UK. $3^{\text {rd }}$ July 2016.

https://www.theguardian.com/science/2016/jul/03/citizen-science-how-internetchanging-amateur-research [last accessed 08/09/2016]

UK Environmental Observation Network, 2012. Understanding Citizen Science and Environmental Modelling: Final Report. Available at 
Published in Castree N., Hulme, M. \& Proctor, J. 2018 Companion to Environmental Studies. Routledge

https://www.ceh.ac.uk/sites/default/files/citizensciencereview.pdf [last accessed 08/09/2016]

Elemental (film) 2012. Directed by Emmanuel Vaughan-Lee and Gayatri Roshan. More information here: http://www.elementalthefilm.com/ 